\title{
COMPARATIVE OF AGROECOLOGICALLY FERTILIZERS WITH MINERAL FERTILIZER IN SECOND CUT SUGARCANE IN THE REGION OF THE SOUTHWEST STATE OF GOIÁS, BRAZIL
}

Joaquim Júlio Almeida Júnior ${ }^{1}$, Danubio Deikti Rodrigues Silva ${ }^{1}$, Edson Lazarini ${ }^{2}$, Katya Bonfim Ataides Smiljanic ${ }^{1}$, Francisco Solano Araújo Matos ${ }^{1}$, Uessiley Ribeiro Barbosa ${ }^{1}$, Victor Júlio Almeida Silva ${ }^{3}$, Beatriz Campos Miranda ${ }^{1}$, Reinaldo Ferreira da Silva ${ }^{1}$, Eder Vaz de Almeida ${ }^{1}$, Adriano Bernardo Leal ${ }^{1}$, Vilmar Neves de Rezende Júnior ${ }^{1}$

\footnotetext{
${ }^{1}$ UniFIMES - University Center of Mineiros, Mineiros, Brazil. E-mail: joaquimjuliojr@gmail.com, danubiodeikti@gmail.com, katya@unifimes.edu.br, solano@unifimes.edu.br, uessiley@unifimes.edu.br, beatrizcamposbeautiful@gmail.com,reinaldo.agro2018@gmail.com, ederalmeidafaz@yahoo.com.br, adrianobleal2015@gmail.com,junior.rzz30@gmail.com

2 Júlio de Mesquita Filho São Paulo State University, Ilha Solteira, Brazil. E-mail: lazarini@agr.feis.unesp.br

${ }^{3}$ Almeida Rodrigues College - FAR, Rio Verde, Brazil. E-mail: vj.rv@ hotmail.com
}

\section{ABSTRACT}

This work evaluated the second cut of the technological variables "plant biometrics" of sugarcane culture using different fertilizers and different doses of organomineral fertilizers in the southwestern region of Goiás, Brazil. The experiment was conducted in the 2017/2018 harvest, in Mineiros, state of Goiás, Brazil. Initial and final plant population, tons of cane per hectare, total recovered sugar, plant height, stalk diameter, and internodes number were evaluated. There were eight procedures with three different dosages of organominerals, three dosages of poultry beds, one chemical fertilizer, and control distributed in randomized blocks with four repetitions. It can be concluded that the poultry bed is excellent for keeping technological variables tested in the best achieved means, with the two main parameters tons of cane per hectare (TCH) and total recovered sugar (TRS) being statistically equal when compared to mineral fertilizer.

Keywords: Agroecological, alternative fertilizer, productivity, Saccharum spp. 


\section{COMPARATIVO EM CANA DE SEGUNDO CORTE ENTRE FERTILIZANTES \\ AGROECOLOGICAMENTE CORRETOS COM FERTILIZANTE MINERAL NA REGIÃO DO SUDOESTE GOIANO}

\section{RESUMO}

Este trabalho avaliou em segundo corte as variáveis tecnológicas "biometria de planta" da cultura da cana-de-açúcar com a utilização de fertilizantes orgânicos e mineral com diferentes doses por fertilizante na região do sudoeste goiano. $\mathrm{O}$ experimento foi conduzido na safra 2017/2018, em Mineiros, Goiás, Brasil população de planta inicial e final, tonelada de cana por hectare, açúcar total recuperado, altura de planta, diâmetro de colmo, e número de entrenós foram avaliados. Foram oito tratamentos com três dosagens diferentes de organominerais, três dosagens de cama de aviário, uma de adubo químico e testemunha distribuídas em blocos casualizados com quatro repetições. A cama de aviário é uma excelente opção por manter as variáveis tecnológicas testadas dentro das melhores médias alcançadas, sendo que os dois principais parâmetros tonelada de Cana por hectare (TCH) e açúcar total recuperado (ATR) foram iguais estatisticamente, em comparação ao fertilizante mineral.

Palavras-chave: Agroecológico, fertilizante alternativo, produtividade, Saccharum spp.

\section{INTRODUCTION}

Nowadays, sugarcane (Saccharum spp.) is one of most important cultures for Brazilian economy regarding also social and environmental aspects. Brazil is the main sugarcane producer in the world and this agroindustry produces biofuels, alcohol, sugar, and many products used in fertilization and animal feeding, besides generating electric energy, employment and income. It develops its activities in accord with the fundamental principles of sustainability, besides contributing for the reduction of fossil fuels use. Technological advances built from scientific research have transformed the sugarcane culture to an activity that conserves the soil, reduces the use of phytosanitary products, generates few residues and reuses them in the productive process, and, in mechanized areas, has been progressively eliminating the practice of straw burning.

Sugarcane belongs to the Poaceae family, being a semi-perennial plant which photosynthesizes via $\mathrm{C} 4$ and has great sucrose storing capacity in the stalk tissues, making it 
extremely important for agribusiness (TEJERA et al., 2007). In Brazil, it found large farmable areas, degraded pastures for cultivation, and conditions of climate and soil favorable to the culture growth and development. According to Conab (2020), the first estimative for the 2020/21 crop demonstrates that 630,7 million tons will be harvested, values that are $1.9 \%$ lower in relation to the 2019/20 crop. In the Brazilian Center-West, it is expected a reduction of $1.2 \%$ in harvested area, reaching 1,795.5 thousand hectares and 138,9 million tons harvested, leading to a production $1.1 \%$ lower than the previous crop values.

In search for sustainability in agriculture, fertilization is one important factor in the determination of productivity and the ideals are the ones that can be alternative to chemical fertilization. For Benites (2011), the Center-West region stands out by the poultry expansion in the last years, generating a great quantity of poultry beds which has been adequately destined as organic fertilizers, rich in nutrients and available in abundance to plants, with low cost and viable for the use in agriculture as an alternative to the chemical fertilizer. The use of poultry beds as organic fertilizer is a sustainable practice because it respects the environment limits since it allows that a contaminant residue can be transformed into an input for agriculture.

Organomineral fertilizers are composed by mixtures of organic and mineral fertilizers that pass through homogenization and pelletizing by extrusion processes, in which it acquires high resistance, which avoids the fragmentation and loss of components (TEIXEIRA et al., 2014). They can contribute to a higher efficiency of fertilization due to their slow liberation of mobile elements in the soil and to their alteration in the natural process of phosphorus fixation which increases the availability to plants for a longer period of time. They are free of pathogenic elements and weed viable seeds because of the complex processing in which they are constituted, bringing sustainable benefits such as the capacity of recovering the soil microbiota and reducing acidity, contributing to the root development.

In face of this, the work aimed at evaluating, in second cut, the technological variables "plant biometrics" of the sugarcane (Saccharum spp.) culture with the use of different fertilizers and different doses per fertilizers, in southwestern Goiás region, in Brazil. 


\section{MATERIAL AND METHODS}

The experiment was conducted in the 2017/2018 crop, at the experimental area of the Center of Study and Research in Phytotechny, in the municipality of Mineiros, state of Goiás, Brazil. The location presents coordinates $17^{\circ} 58^{\prime} \mathrm{S}$ of latitude and $45^{\circ} 22^{\prime} \mathrm{W}$ of longitude and $845 \mathrm{~m}$ of altitude.

The predominant climate in the region, according to Alvares et al (2013), is Aw, which is defined as humid tropical with rain in summer and drought in winter. The annual rainfall is 1830 $\mathrm{mm}$, with annual mean temperature of approximately $25^{\circ} \mathrm{C}$ and annual mean air relative humidity of $66 \%$ (Figure 1). The rainy period goes from October to March, with December, January and February composing the rainiest trimester, and the driest trimester is June, July and August (mean of $27 \mathrm{~mm})$.

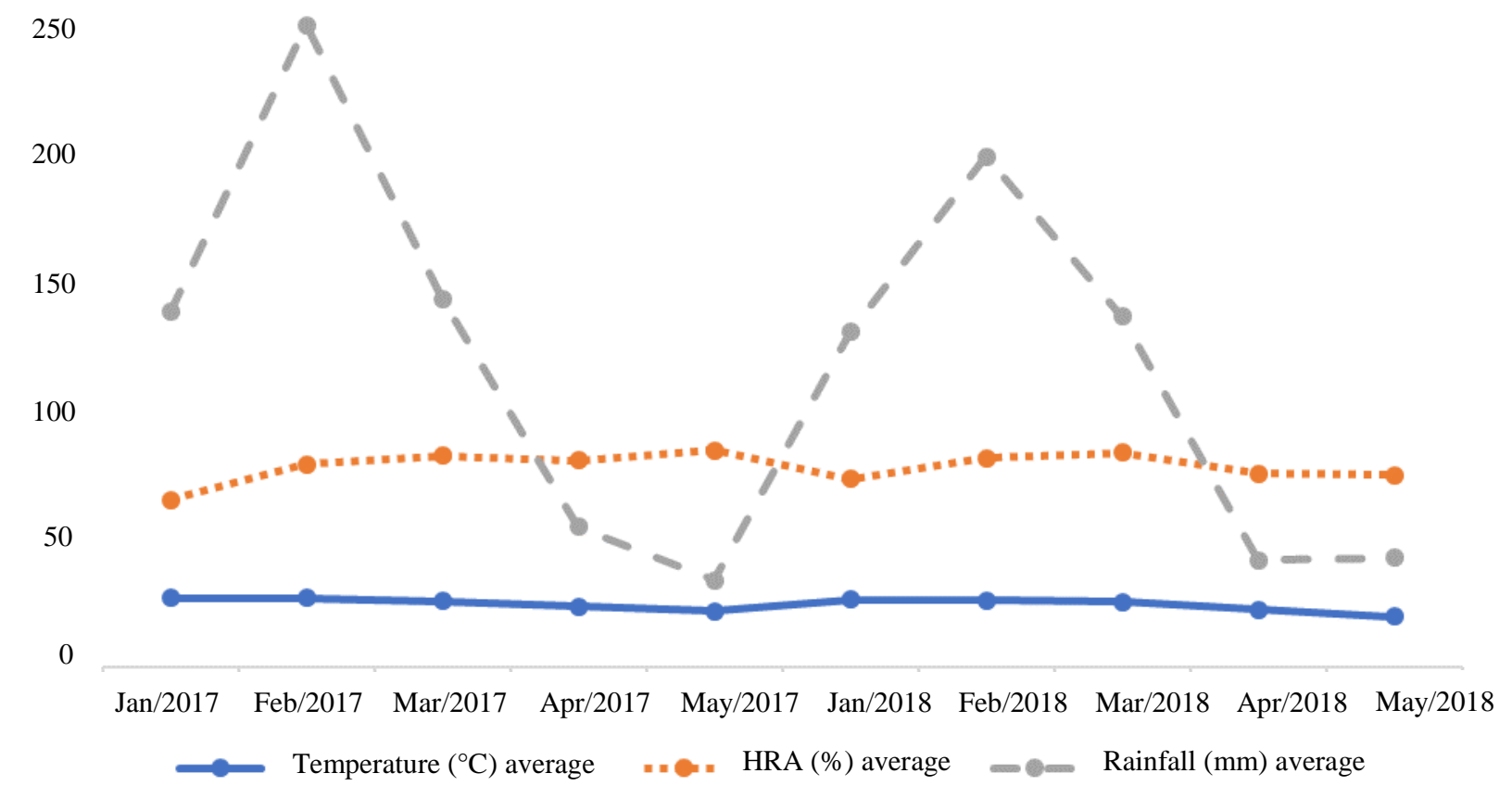

Figure 1. Monthly average temperatures $\left({ }^{\circ} \mathrm{C}\right)$, air relative humidity $(\%)$ and rainfall (mm) accumulated in the 2017/2018 crop at the experimental area of the Center of Study and Research in Phytotechny in the municipality of Mineiros, state of Goiás, Brazil, 2018 (AGRITEMPO - INMET, 2018).

The area predominant soil, following the new denomination of the Brazilian Soil Classification System (EMBRAPA, 2013), is Quartzarenic Neosoil with sandy texture, which was originally occupied by Cerrado vegetation and has been explored by annual cultures for more than 15 years. 
The experimental design was casualized blocks with an $8 \times 1$ scheme and four repetitions. Each experimental parcel was composed of four lines of 4 meters long with usable area of two lines of two meters long and a $50 \mathrm{~cm}$ spacing between lines; with spacing between blocks of 2 meters long.

The evaluated technological variables "plant biometrics" were respectively collected: IPP: Initial plant population [90 days after plantation (DAP)]; TSH: tons of sugarcane per hectare (with 12 months after plantation "first cut"); TRS: Total recovered sugar (the analyzes were conducted 24 hours after the collection of the samples). The other technological variables were collected 1 (one) day before harvest: FPP: Final plant population; PH (m): Plant height; SD (cm): stalk diameter; IN: Internodes number.

The soil attributes were evaluated before the implementation of the research project in order to know the chemical characteristics of the experimental area. There were determined the soil chemical attributes (pH, P, K, Ca, Mg, $\mathrm{H}+\mathrm{Al}, \mathrm{Al}, \mathrm{S} . \mathrm{B}, \mathrm{V}(\%)$, and M.O.) in layers of 0.0 to 0.2 and 0.2 to 0.4 meters of depth, following the methodology proposed by Raij \& Quaggio (2001). The analyzes were conducted in the Laboratory of Soil Fertility of UniFIMES - University Center of Mineiros and are shown in the Table 1.

Table 1. Results obtained in the soil chemical analysis, sample collected in the experimental area stablished at the Center of Study and Research in Phytotechny, in function of crescent doses of fertilizers organomineral (OM) "05-10-10", organic (PB) "poultry bed", mineral (NPK) "05-25-15". Municipality of Mineiros, state of Goiás, Brazil, 2018 (RESEARCH DATA, 2018).

\begin{tabular}{|c|c|c|c|c|c|c|c|c|c|c|c|}
\hline \multirow[t]{2}{*}{ Depth $(\mathrm{cm}$} & $\mathrm{pH}$ & $\mathrm{P}(\mathrm{Mel})$ & $\mathrm{K}^{+}$ & $\mathrm{Ca}$ & $\mathrm{Mg}$ & $\mathrm{Al}$ & $\mathrm{H}+\mathrm{Al}$ & S.B. & CTC & V & M.O. \\
\hline & $\mathrm{CaCl}_{2}$ & $\mathrm{mg} \mathrm{dm}^{-}$ & \multicolumn{7}{|c|}{ mmolc $\mathrm{dm}^{-3}$} & $\%$ & $\mathrm{~g} \mathrm{dm}^{-3}$ \\
\hline $0-20$ & 5.2 & 9.7 & 0.1 & 31 & 9 & 0 & 17 & 40.1 & 44.4 & 57.1 & 24 \\
\hline $20-40$ & 5.5 & 1.2 & 0.1 & 16 & 5 & 0 & 13 & 21.1 & 48.2 & 34.1 & 15 \\
\hline
\end{tabular}

The sugarcane cultivar used was RB86-7515. The treatments were: T1: 0.0 (zero dose of fertilizer) ha ${ }^{-1}$; T2: $300 \mathrm{~kg}$ "Organomineral fertilizer 05-10-10" ha-1; T3: $600 \mathrm{~kg}$ "Organomineral fertilizer 05-10-10" ha-1; T4: 900kg "Organomineral fertilizer 05-10-10" ha $^{-1}$; T5: 5,000 kg "Poultry bed" ha ${ }^{-1}$; T6: 10,000 kg "Poultry bed" ha ${ }^{-1} ;$ T7: 15,000 kg "Poultry bed" ha ${ }^{-1}$; T8: $500 \mathrm{~kg}$ "Mineral fertilizer 05-25-15" ha" . 
Before the implementation of the research project, the poultry bed was chemically analyzed in the Laboratory of Soil, Leaves and Organic Residues of UniFIMES - University Center of Mineiros, with obtained results expressed in Table 2.

Table 2. Results obtained from the chemical analysis of the organic fertilizer "poultry bed", sample collected before plantation of the sugarcane cultivar RB86-7515, which was implemented in the experimental area of the Center of Study and Research in Phytotechny. Municipality of Mineiros, state of Goiás, Brazil, 2018 (RESEARCH DATA, 2018).

MACRONUTRIENTS MICRONUTRIENTS

\begin{tabular}{|c|c|c|c|c|c|c|c|c|c|c|}
\hline \multirow{2}{*}{ ample } & \multicolumn{6}{|c|}{$--(\%)$ dag kg } & \multicolumn{4}{|c|}{ - } \\
\hline & $\mathrm{N}$ & $\mathrm{P}$ & $\mathrm{K}$ & $\mathrm{Ca}$ & $\mathrm{Mg}$ & $\mathrm{S}\left(\mathrm{SO}_{4}\right)$ & $\mathrm{Fe}$ & $\mathrm{Mn}$ & $\mathrm{Cu}$ & $\mathrm{Zn}$ \\
\hline & 52.45 & 3.39 & 13.67 & 15.71 & 0.36 & 5.48 & $14,120.00$ & $4,915.40$ & $2,121.18$ & $15,122.02$ \\
\hline
\end{tabular}

The data were analyzed by the Sisvar software, proposed by Ferreira (2014). The obtained data were submitted to variance analysis, with means compared by T-test, when significance detected for ANOVA at $\mathrm{p}=0.05 \%$ of probability for the comparing of means.

\section{RESULTS AND DISCUSSION}

In the outline of the variance analysis of technologic variables evaluated "plant biometrics" from the sugarcane cultivar RB86-7515, for the "blocks" parameter, it was noted that none of the tested variables presented significant difference at $1 \%$ and $5 \%$ of probability, respectively. For the treatment variance factor, the variable "tons of sugarcane per hectare" presented significance difference (Table 3).

Table 4 demonstrates that the tested variables IPP: Initial plant population; PPF: Final plant population; PH: Plant height (m); and SD (cm): Stalk diameter did not present significant difference between the treatments evaluated. In a work conducted by Perozini et al. (2019) with organic fertilizer "soil conditioner rock powder" from "gabbro basalt", it was found that this is highly viable in the sugarcane production because it keeps high productivity and chemical characteristics at high levels. 
Table 3. Outline of the variance analysis of technologic variables evaluated "plant biometry" from the sugarcane cultivar RB86-7515. Implemented at the Center of Study and Research in Phytotechny, in function of the crescent doses of fertilizers organomineral (OM) "05-1010 ”, organic (CA) "poultry bed", mineral (NPK) “05-25-15”. Municipality of Mineiros, state of Goiás, Brazil, 2018 (RESEARCH DATA, 2018).

\begin{tabular}{|c|c|c|c|c|c|c|c|c|}
\hline $\mathrm{FV}$ & GL & IPP & FPP & $\mathrm{PH}(\mathrm{m})$ & $\mathrm{SD}(\mathrm{cm})$ & IN & $\mathrm{TSH}$ & TRS \\
\hline Block & & ns & ns & ns & ns & ns & ns & ns \\
\hline Treatments & & ns & ns & ns & ns & ns & $*$ & ns \\
\hline Residue & & - & - & - & - & - & - & - \\
\hline $\mathrm{CV}(\%)$ & - & 12.39 & 7.81 & 9.87 & 6.49 & 10.77 & 12.55 & 9.30 \\
\hline DMS & - & 4.47 & 2.91 & 0.66 & 0.47 & 4.58 & 48.49 & 32.33 \\
\hline
\end{tabular}

Table 4. Mean of technologic variables evaluated "plant biometry" for sugarcane cultivar RB867515. Implemented at the Center of Study and Research in Phytotechny, in function of crescent doses of fertilizers organomineral (OM) "05-10-10", organic (CA) "poultry bed”, mineral (NPK) “05-25-15”. Municipality of Mineiros, state of Goiás, Brazil, 2018 (RESEARCH DATA, 2018).

\begin{tabular}{cccccc}
\hline TREAT & D kg ha & IPP & FPP & PH $(\mathrm{m})$ & SD $(\mathrm{cm})$ \\
\hline 1 & Zero & 15.25 & 15.50 & 2.53 & 3.05 \\
2 & $300 \mathrm{OM}$ & 14.75 & 17.00 & 2.67 & 3.34 \\
3 & $600 \mathrm{OM}$ & 15.25 & 15.25 & 3.01 & 2.96 \\
4 & $900 \mathrm{OM}$ & 14.75 & 15.50 & 2.96 & 3.14 \\
5 & $5,000 \mathrm{CA}$ & 15.50 & 16.25 & 2.95 & 2.87 \\
6 & $10,000 \mathrm{CA}$ & 15.50 & 15.75 & 2.72 & 3.06 \\
7 & $15,000 \mathrm{CA}$ & 16.00 & 15.75 & 3.00 & 2.98 \\
8 & $500 \mathrm{MPK}$ & 14.75 & 14.75 & 2.87 & 3.05 \\
\hline CV $(\%)$ & - & 12.39 & 7.81 & 9.87 & 6.49 \\
\hline DMS & - & 4.47 & 2.91 & 0.66 & 0.47
\end{tabular}

TREAT: Treatments; D t and $\mathrm{kg} \mathrm{ha}^{-1}$ : Dose in kilogram per hectare; IPP: Initial plant population; FPP: Final plant population; PH: Plant height (m); SD (cm): Stalk diameter. Means without letters in the column did not significantly differ at $5 \%$ of probability by $\mathrm{T}$-test.

Table 5 shows that for the technologic variable "tons of sugarcane per hectare", significant difference between tested treatments was observed, with the treatments with higher numbers of tons of sugarcane per hectare being found in treatments T8, T7, T6, and T5 with respective means 
of 206.65; 194.98; 188.32; and 168.32 tons of sugarcane per hectare. The variable with lower mean was found in the treatment T1 "negative control", a mean of 103.32 tons of sugarcane per hectare. In a work conducted by Almeida Júnior et al. (2019), it was concluded that the organic fertilizer "rock powder" from "gabbro basalt" is viable for the production of sugarcane because it keeps the quality of primary material for the industrial use besides contributing to the reduction of production costs.

Table 5. Means of technological variables evaluated "plant biometry" for sugarcane cultivar RB867515. Implemented at the Center of Study and Research in Phytotechny in function of crescent doses of fertilizers organomineral (OM) "05-10-10", organic (CA) "poultry bed", mineral (NPK) "05-25-15”. Municipality of Mineiros, state of Goiás, Brazil, 2018 (RESEARCH DATA, 2018).

\begin{tabular}{ccccc}
\hline TREAT & Dose kg ha & NE & TCH & ATR \\
\hline 1 & Zero & 17.16 & $103.32 \mathrm{~d}$ & 136.00 \\
2 & $300 \mathrm{OM}$ & 18.50 & $143.31 \mathrm{~cd}$ & 143.75 \\
3 & $600 \mathrm{OM}$ & 18.66 & $148.32 \mathrm{bcd}$ & 141.75 \\
4 & $900 \mathrm{OM}$ & 17.25 & $149.99 \mathrm{bcd}$ & 148.75 \\
5 & $5,000 \mathrm{CA}$ & 18.25 & $168.32 \mathrm{abc}$ & 152.25 \\
6 & $10,000 \mathrm{CA}$ & 17.33 & $188.32 \mathrm{abc}$ & 147.50 \\
7 & $15,000 \mathrm{CA}$ & 17.25 & $194.98 \mathrm{ab}$ & 153.25 \\
8 & $500 \mathrm{MPK}$ & 18.91 & $206.65 \mathrm{a}$ & 148.50 \\
\hline CV $(\%)$ & - & 10.77 & 12.55 & 9.30 \\
\hline DMS & - & 4.58 & 48.49 & 32.33
\end{tabular}

TREAT: Treatments; $\mathrm{D}$ t and $\mathrm{kg} \mathrm{ha}^{-1}$ : Dose in kilogram per hectare; IN: Internodes number; TSH: Tons of sugarcane per hectare; TRS: Total recovered sugar. Means without letters in the column did not differ significantly at $5 \%$ of probability by T-test.

It can be observed (Figure 2) the polynomial curve for the technologic variable "tons of sugarcane per hectare", where the highest internodes number was found in treatment T8 with a mean of 206.65 tons per hectare and the lowest value was found in treatment T1 "negative control", with a mean of 103.32 tons of sugarcane per hectare. 


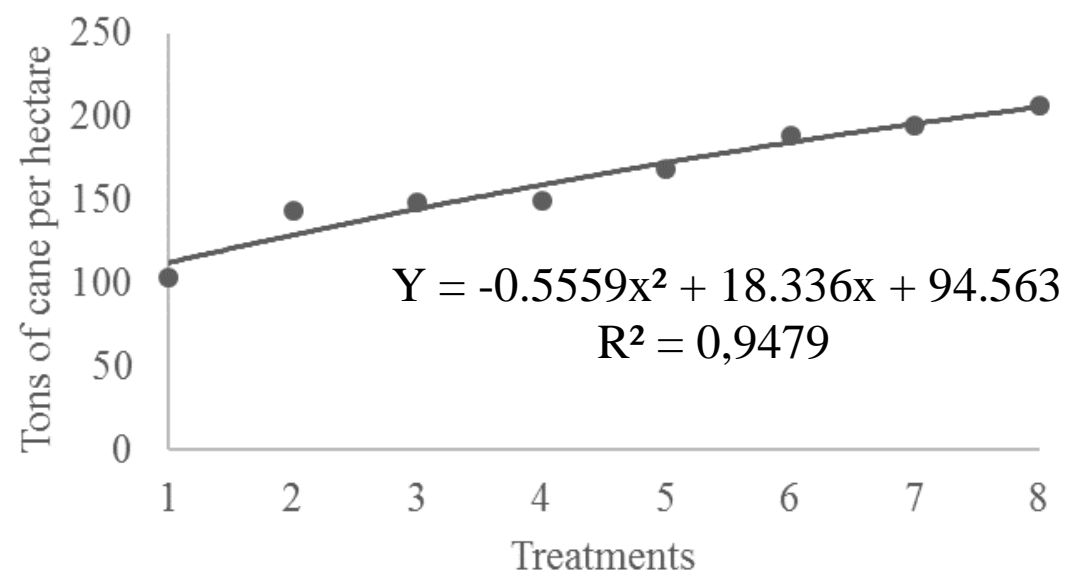

Figure 2. Polynomial curve for technologic variable "tons of sugarcane per hectare" for sugarcane cultivar RB96-7515. Implemented at Center of Study and Research in Phytotechny in function of crescent doses of fertilizers organomineral (OM) "05-10-10", organic (CA) "poultry bed”, mineral (NPK) "05-25-15”. Municipality of Mineiros, state of Goiás, Brazil, 2018 (RESEARCH DATA, 2018).

\section{CONCLUSIONS}

Poultry bed is an excellent option because it kept the tested technological variables within the best means reached, with the two main parameters TSH and TRS were statistically equal when comparing to the mineral fertilizer. Yet, it contributes to the poultry industry sustainability, allocating the derived residues in an adequate way.

\section{ACKNOWLEDGEMENTS}

To Center of Study and Research in Phytotechny for contributing with supplies used in this research along with technical information. To the academicians from the Agronomical Engineering course (UniFIMES - University Center of Mineiros) for the participation in the work development.

\section{REFERENCES}

AGRITEMPO, 2018. Sistema de Monitoramento Agrometeorológico Mineiros (INMET). Município de Mineiros, Estado de Goiás, 2018. Available at: <https://www.agritempo.gov.br/agritempo/produtos.jsp?siglaUF=GO> Acessed on: Nov. 20, 2019. 
ALMEIDA JÚNIOR, J. J; SMILJANIC, K. B. A; MATOS, F. S. A; LEAL, A. B; RUBIO, G. O; MORAES, C. A. C., 2019. Avaliação dos componentes químicos da parte aérea da cana-deaçúcar tratada com doses crescentes do condicionador pó de rocha de origem "basalto gabro" II CONGRESSO NACIONAL DE PESQUISA MULTIDISCIPLINAR ISSN 2527-2500. Available at: <http://publicacoes.unifimes.edu.br/index.php/coloquio/article/view/679> Acessed on: Jul. 13, 2020.

ALVARES, C. A.; STAPE, J. L.; SENTELHAS, P. C.; GONÇALVES, M. L. J.; GERD, S.; 2013. Köppen's Climate Classification Map for Brazil. Meteorologische Zeitschrift 711-728. Available at: <https://doi.org/10.1127/0941-2948/2013/0507> Accessed on: Jul. 13, 2020.

BENITES, V., 2011. Produção de fertilizantes organominerais utilizando resíduos orgânicos de sistemas de produção animal: uma alternativa para agregação de valor aos resíduos e redução do impacto ambiental. Embrapa Solos, Sociedade Brasileira dos Especialistas em Resíduos das Produções Agropecuária e Agroindustrial. Informativo VIII, Available at: <https://www.embrapa.br/documents/1355242/0/Biog\%C3\%A1sFert+-

+ Produ $\% \mathrm{C} 3 \% \mathrm{~A} 7 \% \mathrm{C} 3 \% \mathrm{~A} 3 \mathrm{o}+\mathrm{de}+$ fertilizante+organomineral+granulado+a+partir+de+dejeto s+de+su\%C3\%ADnos+e+aves+no+Brasil.pdf> Accessed on: Jun. 12, 2020.

CONAB, 2020 - Companhia Nacional de Abastecimento. Acomp. safra bras. cana, v. 7 - Safra 2019/20, n. 1 - Primeiro levantamento, Brasília, p. 1-62, May 2020. Available at: <https://www.conab.gov.br/info-agro/safras/cana/boletim-da-safra-de-cana-de-acucar> Accessed on: May 12, 2020.

EMBRAPA - Empresa Brasileira de Pesquisa Agropecuária, 2013. Sistema Brasileiro de Classificação de Solos. Brasília, $3^{\mathrm{a}}$ edição, 353 p.

PEROZINI, A. C; ALMEIDA JÚNIOR, J. J; SILJANIC, K. B. A; MATOS, F. S. A; OLIVEIRA, S. M. A; CAMARGO, H. A., 2019. Avaliação das características agronômicas da cana-deaçúcar tratada com doses crescentes do condicionador pó de rocha de origem "basalto gabro". II CONGRESSO NACIONAL DE PESQUISA MULTIDISCIPLINAR ISSN 2527-2500. Available at: <http://publicacoes.unifimes.edu.br/index.php/coloquio/article/view/677> Accessed on: Jul. 13, 2020.

RAIJ, B. V; ANDRADE, J.C.; CANTARELLA, H. \& QUAGGIO, J. A., 2001. Análise química para avaliação da fertilidade de solos tropicais. Campinas: Instituto Agronômico. 285p. Available at: <http://lab.iac.sp.gov.br/publicacoes.html> Accessed on: Jul. 10, 2020.

TEIXEIRA, W. G.; SOUZA, R. T. X. de; KORNDÖRFER, G. H., 2014. Response of sugarcane to doses of phosphorus provided by organomineral fertilizer. Bioscience Journal, Uberlândia, v. $30, \quad$ n. $6, \quad$ p. 1729-1736. Available at: <http://www.seer.ufu.br/index.php/biosciencejournal/article/view/22156/15610> Access on: Jun. 13, 2020.

TEJERA, N. A.; RODÉS, R.; ORTEGA, E.; CAMPOS, R.; LLUCH, C., 2007. Comparative analysis of physiological characteristics and yield components in sugarcane cultivars. Field Crops Research, Amsterdam, v.102, p.64-72. Available at: <http://www.ugr.es/ natejera/TejeraFCR2007.pdf> Accessed on: Jun. 17, 2020. 